\title{
Highly Efficient Sources of Negative Hydrogen Ions
}

\author{
Cooperative Research and Development Agreement \\ Final Report
}

CRADA Number: FRA-2011-0006

\section{Fermilab Technical Contact: Dan Bollinger}

Summary Report

6 January 2020 


\section{NOTICE}

This report was prepared as an account of work sponsored by an agency of the United States government. Neither the United States government nor any agency thereof, nor any of their employees, makes any warranty, express or implied, or assumes any legal liability or responsibility for the accuracy, completeness, or usefulness of any information, apparatus, product, or process disclosed, or represents that its use would not infringe privately owned rights. Reference herein to any specific commercial product, process, or service by trade name, trademark, manufacturer, or otherwise does not necessarily constitute or imply its endorsement, recommendation, or favoring by the United States government or any agency thereof. The views and opinions of authors expressed herein do not necessarily state or reflect those of the United States government or any agency thereof.

Available electronically at http://www.osti.gov/bridge

Available for a processing fee to U.S. Department of Energy and its contractors, in paper, from:

U.S. Department of Energy Office of Scientific and Technical Information

P.O. Box 62

Oak Ridge, TN 37831-0062

phone: 865.576 .8401

fax: 865.576.5728

email: mailto:reports@adonis.osti.gov

Available for sale to the public, in paper, from:

U.S. Department of Commerce

National Technical Information Service

5285 Port Royal Road

Springfield, VA 22161

phone: 800.553 .6847

fax: 703.605.6900

email: orders@ntis.fedworld.gov

online ordering: http://www.ntis.gov/ordering.htm 
In accordance with Requirements set forth in Article XI.A(3) of the CRADA document, this document is the final CRADA report, including a list of Subject Inventions, to be forwarded to the Office of Science and Technical Information as part of the commitment to the public to demonstrate results of federally funded research.

CRADA number: $\quad$ FRA-2011-0006

CRADA Title: $\quad$ Highly Efficient Sources of Negative Hydrogen Ions

Parties to the Agreement: $\quad$ MUONS, Inc and Fermi Research Alliance, LLC

\section{Abstract of CRADA work:}

Fermilab will provide technical expertise to help Muons, Inc. develop novel modifications of $\mathrm{H}$ source designs which will satisfy the performance requirements of Project $X$ at Fermilab. The new source will be an advanced version of a Penning DT SPS (Dudnikov-Type Penning Surface Plasma Source) with a high efficiency, deliver up to $15 \mathrm{~mA}$ average current with improved electrode cooling. Supported in part by DOE STTR grant DE-SC0006267.

\section{Summary of Research Results:}

Factors limiting the operating lifetime of Compact Surface Plasma Sources (CSPS) were analyzed and possible treatments for lifetime enhancement considered. Noiseless discharges with lower gas and cesium densities were produced in experiments with modified discharge cells. With these discharge cells it is possible to increase the emission aperture and extract the same beam with a lower discharge current and with correspondingly increased source lifetime.

\section{Related Reports, Publications, and Presentations:}

Dudnikov, Vadim, and Bollinger, Daniel. Highly Efficient Sources of Negative Hydrogen Ions. United States: N. p., 2013.Web.

IPAC'10, Kyoto, Japan, Dudnikov, Vadim and Johnson, Rolland P. High Brightness H- Surface Plasma Sources (THPEC072).

Dudnikov, V, Bollinger, D, and Lawrie, S. Lifetime of Highly Efficient H- Ion Sources. 2013.

Web. (FERMILAB-CONF-12-248-AD) 
Subject Inventions listing:

None

Report Date: 6 January 2020

Technical Contact at Fermilab: Dan Bollinger

This document contains NO confidential, protectable or proprietary information.

July 2013 